\title{
REVIEW
}

\section{Net and gross productivity: weighing in with ${ }^{14} \mathrm{C}$}

\author{
John Marra* \\ Brooklyn College of the City University of New York, Brooklyn, New York 11210, USA
}

\begin{abstract}
Data from the ${ }^{14} \mathrm{C}$ method, $\mathrm{C}$ assimilation time courses and single endpoint comparisons to $\mathrm{O}_{2}$ fluxes, imply 2 different things. Time course (linear) experiments suggest that $\mathrm{C}$ assimilation measures gross production while the single endpoint comparisons with $\mathrm{O}_{2}$ fluxes suggest that the ${ }^{14} \mathrm{C}$ method approximates net community production. Considering only phytoplankton metabolism, a way out of the paradox is to assume that all $\mathrm{CO}_{2}$ respired by mitochondria is refixed in photosynthesis, meaning that photosynthesis uses more $\mathrm{H}_{2} \mathrm{O}$ than $\mathrm{CO}_{2}$ from the ambient environment since the latter has an internal source. The ${ }^{14} \mathrm{C}$ method, therefore, would estimate net primary production relative to $\mathrm{O}_{2}$ fluxes in the absence of heterotrophic interactions. The method can also be applied to the estimation of phytoplankton respiration from the nighttime loss of labeled organic matter. A summary of available data shows that $\mathrm{C}$ assimilation corrected for organic $\mathrm{C}$ lost is statistically equivalent to gross production measured independently using the ${ }^{18} \mathrm{O}$ method.
\end{abstract}

KEY WORDS: Productivity $\cdot$ Phytoplankton $\cdot$ Photosynthesis $\cdot{ }^{14} \mathrm{C} \cdot$ Refixation

Resale or republication not permitted without written consent of the publisher

\section{INTRODUCTION}

Phytoplankton, the microscopic flora inhabiting all aquatic environments, form the base of aquatic food webs and perform the most important step in the Earth's C cycle: the conversion of inorganic C to organic $\mathrm{C}$ through photosynthesis. Photosynthesis is the mechanism of primary productivity. Primary productivity is of fundamental importance in understanding the structure and function of ocean ecosystems and ocean biogeochemical cycles.

Globally, primary production in the ocean is thought to be in the range of 40 to $70 \mathrm{Pg} \mathrm{C} \mathrm{yr}^{-1}$ (Falkowski et al. 1998, Carr et al. 2006), and is accomplished by a phytoplankton biomass of $\sim 1 \mathrm{Pg}$ C. Therefore, phytoplankton biomass turns over $\sim 1 \mathrm{wk}^{-1}$. Phytoplankton move about and are being continually stirred and mixed by ocean processes. Their 3-dimensional environment, coupled with their high rate of turnover, make measurement of their population numbers over time difficult; thus, metabolic rates assume overriding importance in the measurement of phytoplankton production. While measuring production on land can be as simple as cutting grass and weighing the clippings, measuring primary production of phytoplankton relies on the measurement of rates of photosynthesis and respiration.

\section{History of the ${ }^{14} \mathrm{C}$ method}

In 1952, E. Steemann Nielsen published his ${ }^{114} \mathrm{C}$ technique,' which is a method for the measurement of photosynthetic production by phytoplankton (Steemann Nielsen 1952). He used results from the method, used during the Galathea expedition in 1950, to illustrate its power, thereby introducing a new means of understanding ocean productivity. ${ }^{14} \mathrm{C}$ had only been discovered $\sim 10$ yr earlier and was used by Calvin in the late 1940s in his classic experiments on C pathways in photosynthesis (see Barber \& Hilting 2002). Steemann Nielsen's method involved the addition of ${ }^{14} \mathrm{C}$ as labeled sodium bicarbonate to a sample of seawater and analysis of the amount of ${ }^{14} \mathrm{C}$ appearing in the particulate matter filtered out of the sample after incubation in the light. The rate of photosynthesis was 
defined as the proportion of ${ }^{14} \mathrm{C}$ in the organic matter relative to the amount of inorganic ${ }^{14} \mathrm{C}$ added, taking into account the concentration of dissolved inorganic $\mathrm{C}$ (DIC) in the seawater. Almost immediately after its introduction, the method came into question (reviewed by Peterson 1980). There were concerns about the effect of respiration, the activities of other heterotrophs, possible artifacts associated with incubation, and other issues. Some of these concerns persist.

The major advantage of the ${ }^{14} \mathrm{C}$ method for measuring photosynthetic $\mathrm{C}$ assimilation in the ocean is its extreme sensitivity. Earlier methods, notably the analysis of $\mathrm{O}_{2}$ changes in incubated samples, cannot easily discriminate the small changes characteristic of many regions of the ocean. The second advantage is the method's relative facility. Handling ${ }^{14} \mathrm{C}$ in the amounts used is safe. It requires, in addition to the isotope, only a means to assay a sample's radioactivity. Third, the method always gives a positive result. These 3 features mean that copious data, all with positive values, can be collected, although historically, such data could not be compared to any other method (Marra 2002).

Nevertheless, much progress has been made with the use of the ${ }^{14} \mathrm{C}$ method for determining oceanic primary production after its introduction by Steemann Nielsen (1952), and we can identify the following series of milestones in its use:

1957. Production of the first productivity map of the ocean in a meeting of the International Council for the Exploration of the Sea.

1970. Publication of a global synthesis of ocean productivity observations using the ${ }^{14} \mathrm{C}$ method (Koblentz-Mishke et al. 1970).

1979-1982. Establishment of 'trace metal clean' protocols for sampling and incubation (Fitzwater et al. 1982).

1982-1985. Intercomparison of various measures and methods to determine primary production in the program Plankton Rate Processes in Oligotrophic Oceans (PRPOOS).

1989-1999. Establishment of international protocols for measuring primary production by the Joint Global Ocean Flux Study (JGOFS).

2002. Conference on 'Plankton production in aquatic environments' and publication of a book (Williams et al. 2002) commemorating the 50th anniversary of the introduction of the ${ }^{14} \mathrm{C}$ technique.

The ${ }^{14} \mathrm{C}$ method remains the pre-eminent means of measuring rates of oceanic production. There are now other means of measuring the rates of oceanic production, e.g. measurements of fluorescence variables or the isotopic composition of surface waters. Moreover, there are more advanced means of sampling the ocean, e.g. optics or satellite-derived ocean color. However, these methods are assessed by their correspondence with ${ }^{14} \mathrm{C}$ uptake. The results from ${ }^{14} \mathrm{C}$ uptake are used (1) for validating algorithms for calculating primary production from space (Carr et al. 2006); (2) in conjunction with studies of export production (Buessler et al. 1992); (3) in food web studies (Marra et al. 1988, Brown et al. 2002), (4) to derive physiological parameters for phytoplankton (Johnson et al. 2002), and (5) in estimating phytoplankton growth rates (Eppley 1972).

\section{Methodological concerns}

As mentioned above, despite its widespread use, there have always been questions concerning the ${ }^{14} \mathrm{C}$ method. One recurring concern is the effect of the incubation container on metabolic processes, the socalled 'bottle effect.' Bottle effects may be apparent over long incubation times and are thought to arise from (1) contamination from the vessel walls, (2) the loss of turbulence, (3) wall growth, and (4) damage to organisms. P. J. LeB. Williams (pers. comm.) analyzed each of these in turn and concluded that anomalies found in incubations are most likely caused by other factors. For example, turbulence theory suggests that it will only affect organisms that are of mesozooplankton size, since the bulk of the plankton exists in a viscous environment (low Reynolds numbers). Also, his analyses suggest that it would take $>1 \mathrm{~d}$ for a significant number of motile bacteria in a standard-sized incubation bottle to encounter a bottle wall, where they might be subject to greater predation anyway. Contamination from incubation vessel walls or added isotope may have been a problem in early work, but this issue has since been resolved and appropriate correctives prescribed (Fitzwater et al. 1982).

Beyond bottle effects, there have been concerns in terms of comparison to other methods and whether incubations represent in situ dynamics. The first of these addresses the question of whether the ${ }^{14} \mathrm{C}$ method measures gross production, net production, or something in between. A related issue is that estimates of phytoplankton respiration in natural populations have seemed out of reach given available methods. In the following sections, I discuss the issue of net vs. gross production, the relationship of incubation methods to in situ dynamics, and a method based on ${ }^{14} \mathrm{C}$ that may yield estimates of phytoplankton respiration.

\section{DATA SOURCES}

The data considered here originate from 3 programs: Plankton Rate Processes in Oligotrophic Oceans 
(PRPOOS) in 1982, Marine Light-Mixed Layers (MLML) in 1991, and the Joint Global Ocean Flux Study (JGOFS) in 1989-1999. PRPOOS sampled waters off Oahu Island (Hawaii): in Kaneohe Bay, south of Honolulu, and near Kahe Point. ML-ML took place south of Iceland $\left(59^{\circ} \mathrm{N}, 21^{\circ} \mathrm{W}\right.$; Marra 1995). 'Process studies' in JGOFS were carried out in the North Atlantic, the equatorial Pacific, the Arabian Sea, and the Southern Ocean. For ML-ML and JGOFS, productivity measurements were done with consistent measurement protocols using in situ incubations (Knudson et al. 1989, Barber et al. 1996). The data from JGOFS (and their contributors) are available at http://usjgofs.whoi.edu.

\section{${ }^{14}$ C UPTAKE: NET OR GROSS PRODUCTION?}

\section{Time course and single endpoint incubations}

Fig. 1 shows data from 4 JGOFS process studies, in which $24 \mathrm{~h}{ }^{14} \mathrm{C}$ assimilation approximates daily net community production $\left(\mathrm{NCP}\right.$, based on $\left.\mathrm{O}_{2}\right)$, but is perhaps slightly higher. The measures differ because ${ }^{14} \mathrm{C}$ assimilation always returns a positive result, whereas NCP can be either positive or negative. Thus, over $24 \mathrm{~h},{ }^{14} \mathrm{C}$ uptake will be 'between net and gross production,' which is a common conclusion regarding what the method is purported to measure. As will be pointed out below, I conclude from the available evi-

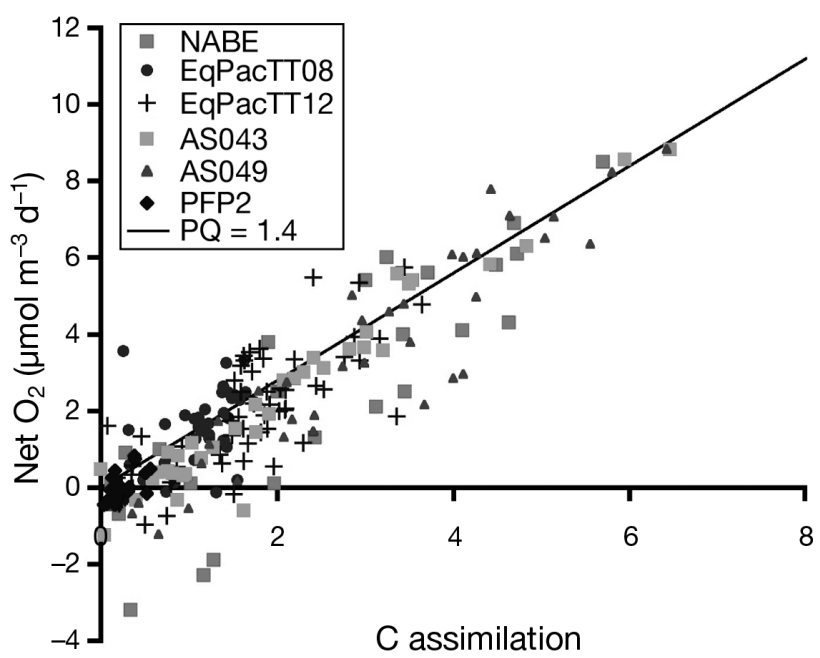

Fig. 1. Comparison of $24 \mathrm{~h}$ rate of net oxygen production measured using the light-dark $\mathrm{O}_{2}$ method, with $24 \mathrm{~h} \mathrm{C}$ assimilation measured using the ${ }^{14} \mathrm{C}$ method. Data are from various Joint Global Ocean Flux Study (JGOFS) process studies (inset legend); NABE: North Atlantic Bloom Experiment, EqPac: Equatorial Pacific Process Study (cruises TT08, TT12), AS: Arabian Sea Expedition (cruises TT043, TT049), PFP2: Polar Front Process 2 cruise from Antarctic Ecosystem, Southern Ocean Process Study. PQ = photosynthetic quitient. Data are available at http://usjgofs.whoi.edu dence that ${ }^{14} \mathrm{C}$ uptake over daytime (dawn-dusk) periods estimates net primary production (NPP). Where there are no measurements to discriminate NCP from NPP, I will simply use the term 'net production.'

Fig. 2 shows 2 time courses of $\mathrm{C}$ assimilation measured via the ${ }^{14} \mathrm{C}$ method, including net $\mathrm{O}_{2}$ production and ${ }^{18} \mathrm{O}$ gross primary production (GPP). Each time course has a different relationship to the single endpoint measurements of ${ }^{18} \mathrm{O}$ GPP and net $\mathrm{O}_{2}$ community production. As with the JGOFS data (Fig. 1), ${ }^{14} \mathrm{C}$ approximates NCP from $\mathrm{O}_{2}$ fluxes, although ${ }^{14} \mathrm{C}$ is closest to GPP when NCP is near 0 or is negative (Williams et al. 1983). However, for both experiments, C assimilation is linear over time during the day. That $\mathrm{C}$ assim-

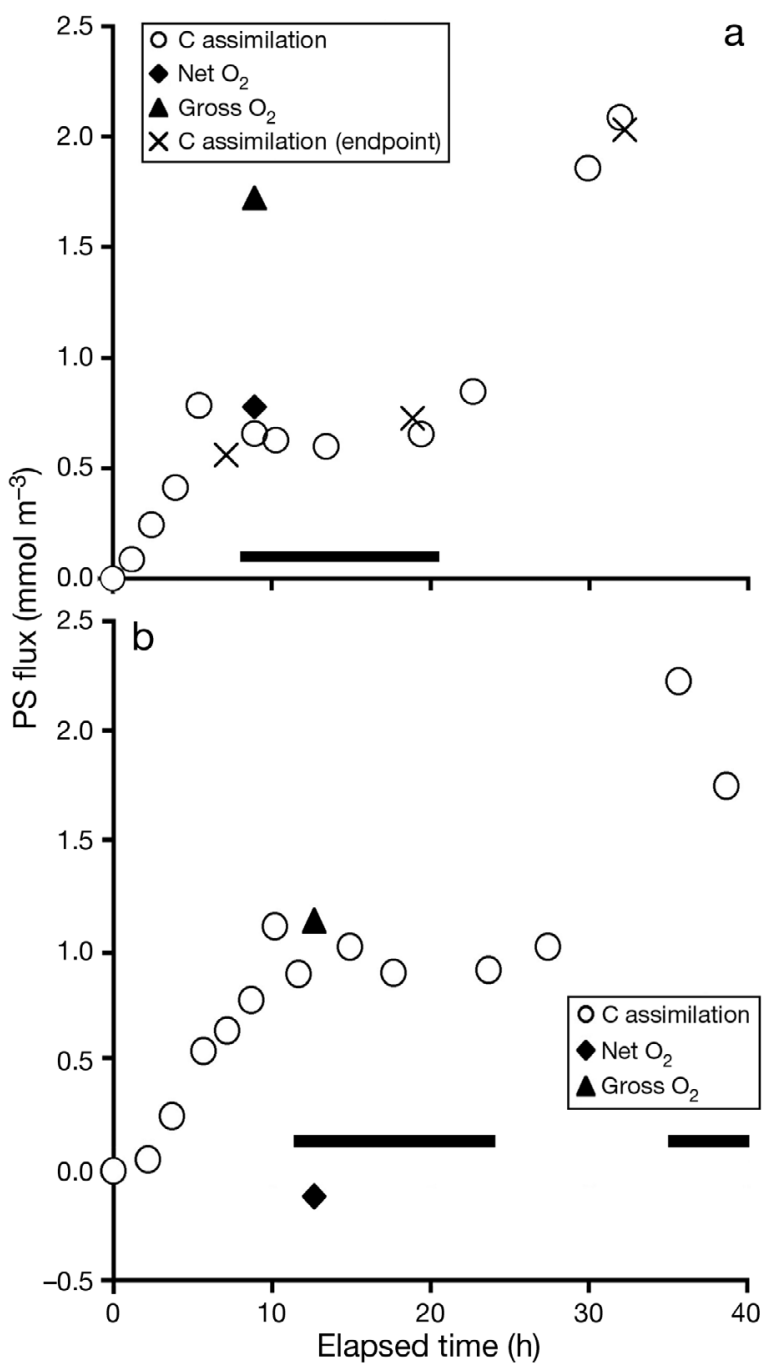

Fig. 2. Time courses of ${ }^{14} \mathrm{C}$ assimilation with other measures. (a) For 3-4 Sept 1982; the incubation began at 10:30 h, (b) for 10-11 Sept 1982. Horizontal bars indicate nighttime periods. Note negative net $\mathrm{O}_{2}$ production after $12 \mathrm{~h}$ incubation. $\mathrm{O}_{2}$ production values are from P. J. LeB. Williams \& D. Purdie (unpubl. data) ${ }_{i}{ }^{18} \mathrm{O}$ gross production values are from K. Grande \& M. Bender (unpubl. data) 
ilation measured using the ${ }^{14} \mathrm{C}$ method is linear over time has been repeatedly found, both in natural populations and in the laboratory (Li \& Goldman 1981, Smith \& Platt 1984, Marra et al. 1988). Dring \& Jewson (1982), using both tracer kinetic theory and observations, analyzed $\mathrm{C}$ assimilation time courses. Because they observed assimilation to be linear over time, they concluded that ${ }^{114} \mathrm{C}$ uptake is proportional to gross photosynthesis' (Dring \& Jewson 1982, p. 365).

The data in Figs. 1 \& 2 thus imply 2 different things. The single endpoint measurements in Fig. 1 suggest that ${ }^{14} \mathrm{C}$ estimates net production, yet for others (Dring \& Jewson 1982), the linear time courses mean that ${ }^{14} \mathrm{C}$ estimates gross production. A way to solve this paradox is to assume that $\mathrm{CO}_{2}$ respired by phytoplankton is retained within the cell and refixed in photosynthesis (Ryther 1956a). Refixation of respired $\mathrm{CO}_{2}$ means that, relative to $\mathrm{O}_{2}$, photosynthesis is using proportionally more ambient $\mathrm{H}_{2} \mathrm{O}$ (the source of evolved $\mathrm{O}_{2}$ ) than $\mathrm{CO}_{2}$ (Fig. 3). Thus, $\mathrm{C}$ uptake during the day should always be less than the $\mathrm{O}_{2}$ fluxes because there is a source for $\mathrm{C}$ within the cell (mitochondrial respiration). Of course there is an intracellular source of water, but comparisons with GPP require the addition of ${ }^{18} \mathrm{O}$-labeled $\mathrm{H}_{2} \mathrm{O}$ to the seawater. In this case, the ${ }^{14} \mathrm{C}$ method will be closest to NPP relative to $\mathrm{O}_{2}$ evolution (Marra 2002).

Alternatively, C can also be sequestered via synthetic pathways (Smith \& Platt 1984). Both refixation and sequestration via synthetic pathways can explain the data, although there is extensive evidence for refixation of respired $\mathrm{CO}_{2}$. Ryther (1956a) was perhaps the first to suggest that refixation can explain why the ${ }^{14} \mathrm{C}$ method should measure net photosynthesis relative to $\mathrm{O}_{2}$ fluxes. Raven (1972) describes further evidence of refixation of respiratory $\mathrm{CO}_{2}$. Dring \& Jewson

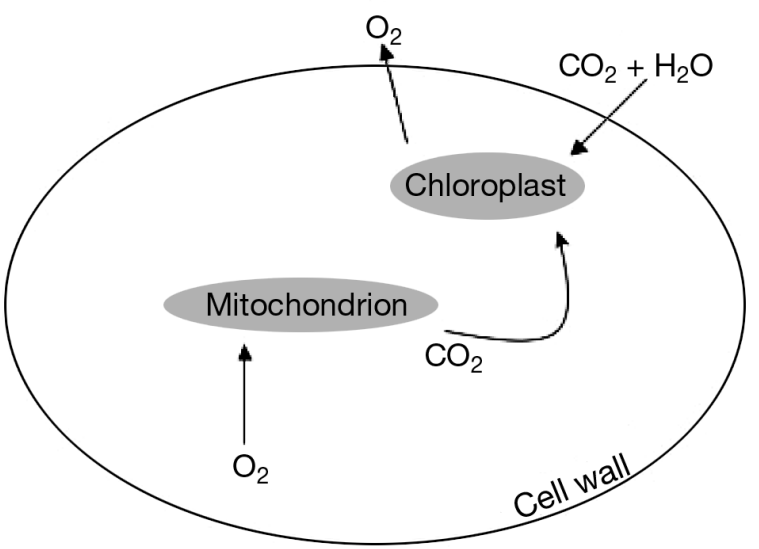

Fig. 3. Diagram of $\mathrm{CO}_{2}$ and $\mathrm{O}_{2}$ fluxes inside a phytoplankton cell, showing refixation of respired $\mathrm{CO}_{2}$ and therefore the imbalance between $\mathrm{C}$ assimilation and $\mathrm{O}_{2}$ efflux. If refixation is occurring, excess ambient $\mathrm{H}_{2} \mathrm{O}$ is reduced relative to ambient $\mathrm{C}$ assimilated, which will affect comparisons that use ${ }^{18} \mathrm{O}$ labeled $\mathrm{H}_{2} \mathrm{O}$ (Bender et al. 1992)
(1982) reject the mechanism of refixation based on the work of Bidwell (1977), and historical evidence has been conflicting. Steemann Nielsen (1955) reports a loss of previously fixed ${ }^{14} \mathrm{C}$ in Chlorella in short-term (2 to $3 \mathrm{~h}$ ) experiments. Ryther (1956b), however, in an experiment where Dunaliella cells were uniformly labeled with ${ }^{14} \mathrm{C}$ (after many generations), presents a result showing no isotope loss after the cells were resuspended and incubated in fresh media, implying refixation of $\mathrm{CO}_{2}$ from respiration. The evidence from natural populations (Fig. 1; Marra 2004) suggests that ${ }^{14} \mathrm{C}$ approximates NCP more closely, and most likely NPP, given the laboratory evidence. Refixation is the most likely mechanism by which the ${ }^{14} \mathrm{C}$ method estimates net production.

Refixation of respiratory $\mathrm{CO}_{2}$ may also explain why ${ }^{14} \mathrm{C}$ appears to estimate gross production when NCP is $<0$. A simple spreadsheet-style accounting of the relationship between $\mathrm{C}$ assimilation and $\mathrm{O}_{2}$ production shows that when 'excess' respiration is included (e.g. heterotrophic respiration), $\mathrm{C}$ assimilation $>>>$ net $\mathrm{O}_{2}$ production (Marra 2002).

\section{Carbon assimilation and in situ fluxes}

\section{North Atlantic Bloom Experiment}

The productivity data for the North Atlantic Bloom Experiment (NABE; $47^{\circ} \mathrm{N}, 20^{\circ} \mathrm{W}$ ) exist in 3 types: the daytime drawdown of $\mathrm{TCO}_{2}$ in the mixed layer, in situ variations in particulate organic $\mathrm{C}$ (POC), and incubation methods (net $\mathrm{O}_{2},{ }^{14} \mathrm{C}$ ). Previously, we observed dawn-to-dusk (14 h) changes in the mixed-layer inventory of $\mathrm{TCO}_{2}$ and favorably compared these with in situ incubations for ${ }^{14} \mathrm{C}$ uptake (Chipman et al. 1993). Fig. 4 (from Marra 2002) shows the comparison of the 3 data types. I have to qualify these results by stating that (1) the sensitivity for the change in $\mathrm{TCO}_{2}$ is low, (2) there are many sources of error, and (3) production did not vary appreciably during the $14 \mathrm{~d}$ period of the measurements. Nevertheless, these data suggest that ${ }^{14} \mathrm{C}$ uptake over the daytime period provides a good estimate of NCP in terms of chemical and particulate C changes in the water column. I have argued elsewhere (Marra 2002) that, in this case, ${ }^{14} \mathrm{C}$ uptake estimates NPP, but since there are no estimates of phytoplankton respiration, the results from the various methods do not permit distinction.

\section{Marine Light-Mixed Layers}

The springtime boreal North Atlantic at the ML-ML site $\left(59^{\circ} \mathrm{N}, 21^{\circ} \mathrm{W}\right)$ represents a very different situation than 


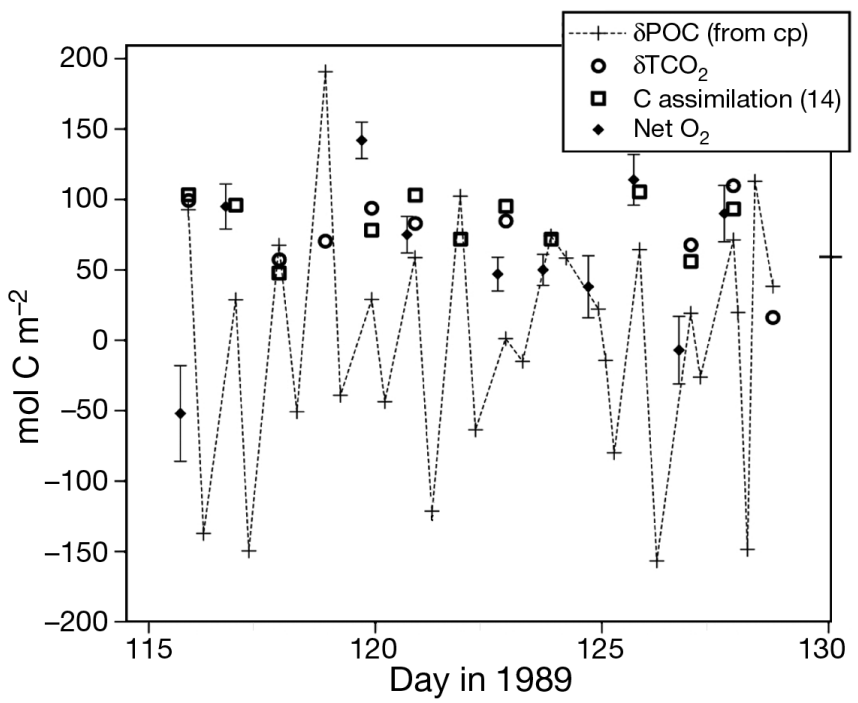

Fig. 4. Comparison of rates determined using incubation methods ( $\mathrm{C}$ assimilation and net $\mathrm{O}_{2}$ production) with rates determined from in situ changes $\left(\delta \mathrm{TCO}_{2}, \delta \mathrm{POC}\right)$ in the mixed layer for the North Atlantic Bloom Experiment (NABE) in 1989 (from Marra 2002). The low points in the SPOC data are rates of loss overnight. The horizontal line on the right $y$-axis indicates the mean of all productivity measurements.

Reproduced with permission from Blackwell Scientific

that in the NABE. Further north, along $20^{\circ} \mathrm{W}$, the water column is highly dynamic. Marra et al. (1995) report the demise of a bloom of Phaeocystis through vigorous mixing, followed by a major storm (wind speed $>30 \mathrm{~m} \mathrm{~s}^{-1}$ ), and the restratification of the water column, all within $9 \mathrm{~d}$ of observations. Table 1 summarizes the productivity data. Estimates of daytime production varied widely until the water column stratified after 23 May. When the mixed layer was deepening, the in situ incubations artificially 'stratified' the samples; thus, the incubations were clearly not representative of water column dynamics.

Although the observations in Table 1 show wide variation, other methods would be similarly biased or ineffective. For example, from 17 to 20 May, chl a levels were $\sim 3 \mathrm{mg}$ chl a $\mathrm{m}^{-3}$ under very cloudy skies

Table 1. Productivity data from Marine Light-Mixed Layers (ML-ML) spring cruise, 1991. All data are in mmol C m${ }^{-2} \mathrm{~d}^{-1}$; $\mathrm{C}_{\mathrm{p}}$ data come from a regression of particulate organic carbon (POC) on beam attenuation

\begin{tabular}{|lccccc|}
\hline Station & $\begin{array}{c}\text { Date } \\
\text { (May) }\end{array}$ & $\begin{array}{c}\text { Mixed layer } \\
\text { depth (m) }\end{array}$ & $\mathrm{C}$ assim. & $\Delta \mathrm{O}_{2}$ & $\Delta \mathrm{c}_{\mathrm{p}}$ \\
\hline 71 & 17 & 24 & 161.0 & -22.60 & -85.20 \\
74 & 20 & 87 & 99.6 & -4.00 & -41.60 \\
76 & 22 & $--^{\mathrm{a}}$ & 93.5 & - & - \\
77 & 23 & 11 & - & 5.99 & 7.70 \\
78 & 24 & 12 & 49.8 & 22.00 & 67.90 \\
alxed layer depths varied too rapidly & over 22 May to \\
allow determination of $\Delta \mathrm{O}_{2}$ or $\Delta \mathrm{c}_{\mathrm{p}}$ \\
\hline
\end{tabular}

before the storm. After the storm, clear skies prevailed, but chl a declined to $0.3 \mathrm{mg} \mathrm{chl} \mathrm{a} \mathrm{m} \mathrm{m}^{-3}$ (a factor of 10). If satellite ocean color had been available, it would not have recorded the Phaeocystis bloom, but only the low chl a values under the clear skies after the storm. Similarly, methods based on atmosphere-ocean imbalances, such as the triple isotope $\mathrm{O}_{2}$ method (Hendricks et al. 2004), require a mixed layer in 'steady state' over periods of days to a week. During the ML-ML cruise, mixed-layer depths were never stable for $>1 \mathrm{~d}$, and at times changed hourly. We have data from moored biooptical sensors during the ML-ML, and these are valuable in observing scalar changes from which productivity can be calculated. However, moored observations generally can be subject to advective variations and are therefore difficult to interpret as a time series. The oceanic regime at ML-ML perhaps represents an extreme, but is worth noting because of the limitations it shows for any method of ocean primary production measurement.

\section{PHYTOPLANKTON RESPIRATION}

Since the beginning of modern ocean productivity studies more than half a century ago, there has never been a verifiable method to estimate phytoplankton respiration in the ocean. Net community respiration can be measured from the consumption of $\mathrm{O}_{2}$ in samples incubated in the dark. However, none of the methods allows the estimation of the respiration by phytoplankton alone, not to mention the separate respiration by heterotrophs. Until now, respiration has always been inferred from laboratory culture or, indirectly, from other kinds of measurements. Oceanographers therefore lack an understanding of a fundamental property of plankton dynamics, leaving a large gap in our knowledge of how biological processes contribute to the ocean's C cycle.

Knowing autotrophic respiration, we can more accurately predict phytoplankton growth rates and their role in the microbial food web. There is also the controversy surrounding the balance of autotrophy and heterotrophy in the ocean. Knowledge of the components of planktonic respiration will allow oceanographers to understand how the balance (or imbalance) is achieved. Although widely accepted, the definition of the euphotic depth (above which photosynthesis exceeds phytoplankton respiration) as the depth of penetration of $1 \%$ of surface irradiance is based more on inference than measurements. Respiration is the biggest unknown factor in our understanding of the $\mathrm{C}$ budget of the ocean. Whether the ocean is a net source or sink for C 'remains an open question' (del Giorgio \& Duarte 2002). 
Geider (1992) reviewed the problem of measuring phytoplankton respiration in nature via an analysis of losses overnight. He noted work done by the PRPOOS investigators, where dark losses ranged from 24 to $36 \%$ of the daytime uptake (Laws et al. 1987, Grande et al. 1989b). Laws et al. (1987), for example, use a model of isotope incorporation (Laws 1984) in an attempt to estimate the phytoplankton fraction of the total loss. Two earlier papers are not mentioned by Geider (1992). The first (Berman \& Kaplan 1984) reports a method similar to that described in the next paragraph (Marra \& Barber 2004). The second (Eppley \& Sharp 1975) uses the difference between half-day and $24 \mathrm{~h}$ rates of $\mathrm{C}$ assimilation as an estimate of dark respiration. Other respiration estimates have been based on the products of photosynthesis: proteins, carbohydrates, and lipids (Li \& Harrison 1982, Lancelot \& Mathot 1985). Although these prior methods have value, in none of them could the estimates of phytoplankton respiration be checked against an independent measure. Thus, estimates of phytoplankton respiration in natural populations have had to rely on conversion efficiencies (Robinson \& Williams 1999) or laboratory data (Langdon 1993).

Marra \& Barber (2004) report a method whereby phytoplankton respiration is estimated separately from community respiration. The method is based on the dark loss of ${ }^{14} \mathrm{C}$, and relies on the following 3 assumptions: (1) ${ }^{14} \mathrm{C}$ and ${ }^{12} \mathrm{C}$ are equally likely to have been respired by the end of a $12 \mathrm{~h}$ incubation; (2) the ${ }^{14} \mathrm{C}$ method measures NPP at the end of a dawn-to-dusk incubation; and (3) phytoplankton respiration during the day is equivalent to respiration at night. If these assumptions can be accepted, then phytoplankton respiration can be calculated as $2 \times$ the dark loss of $\mathrm{C}$ overnight, given a $12 \mathrm{~h}$ light:dark (L:D) cycle. The evidence for assumption (1) is presented by Marra \& Barber (2004), who conclude that the isotopes of $C$ in the phytoplankton are at equilibrium with respect to cellular metabolism. Assumption (2) is discussed above and in Marra (2002). Also, there is a sizeable literature from the 1950 s and 1960 s indicating that the ${ }^{14} \mathrm{C}$ method measures NPP where it can be distinguished from NCP (Marra 2004).

The evidence for assumption (3) is mixed, and is complicated by species variability and the times over which respiration is measured. Both Peltier \& Thibault (1985) (for Chlamydomonas reinhardtii) and Weger et al. (1988) (for Selenastrum minutum) reported equivalence in light and dark respiration over time scales of minutes. A follow-on paper (Weger et al. 1989), using Thalassiosira weisflogii, found an increase in light respiration by a factor of 2 (again for time scales of minutes). Grande et al. (1989a) reported measurements of respiration in the dark and light ( $6 \mathrm{~h}$ incubations), and find equivalence for some species (Emiliania huxleyi, Skeletonema costatum), but that respiration in the light exceeded that in the dark by factors of 2 (Thalassiosira nordenskioldii) to 3 (Protogonyaulax tamarensis). Some species from the Grande et al. (1989a) that study have also been shown to photorespire (e.g. Synechococcus sp.). Recently, Pringault et al. (2007) report light-enhanced dark respiration at high irradiances $\left(1000 \mu \mathrm{mol}\right.$ photons $\left.\mathrm{m}^{-2} \mathrm{~s}^{-1}\right)$ in a eutrophic lagoon. Their measurements are based on $\mathrm{O}_{2}$, and assume that the first few minutes in the dark are representative of respiration in the light. The measurements include bacterial respiration, which is also light dependent (Pringault et al. 2008). Overall, the evidence to support assumption (3) is inconsistent and reflects the difficulty of the measurements. Clearly, before making any conclusions about the equivalence of day and night respiration, more research needs to be done applying the appropriate time scales and using both $\mathrm{C}$ and $\mathrm{O}_{2}$ fluxes. The analysis of $\mathrm{C}$ loss in Laws et al. (2000) also requires that day and night respiration be equal, and indeed, the dissolved $\mathrm{O}_{2}$ light-dark bottle method itself relies on the equivalence of respiration in the light and in the dark to calculate GPP.

Fig. 5 is a collection of the data from Marra \& Barber (2004) plus additional data from the Arabian Sea Expedition and from the PRPOOS project in 1985 (see

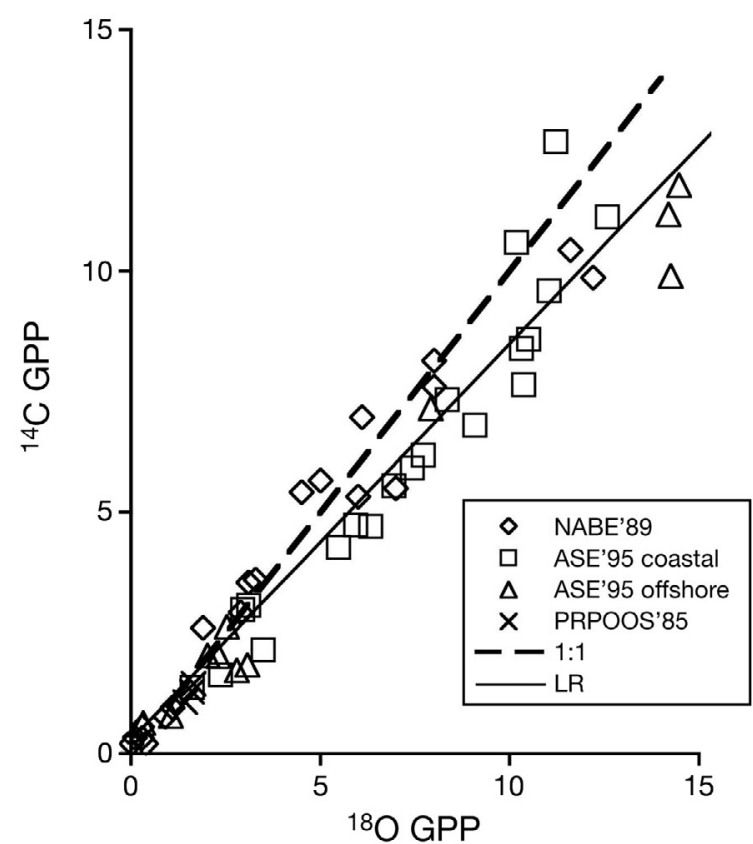

Fig. 5. Comparison of data for phytoplankton gross photosynthesis (daytime assimilation $+2 \times$ the overnight dark loss) from ${ }^{14} \mathrm{C}$ incubation experiments $\left({ }^{14} \mathrm{C}\right.$ GPP), with independently measured ${ }^{18} \mathrm{O}$ gross primary production $\left({ }^{18} \mathrm{O}\right.$ GPP). (- - -) expected 1:1 relationship, (-) Model II regression, which has a slope of $0.86 \pm 0.027$, an intercept of $0.143 \pm 0.19$, and an $\mathrm{r}^{2}=0.94$ 
Grande et al. 1989a). As in Marra \& Barber (2004), the comparison shown is indirect because we have no measurements of phytoplankton respiration. Therefore, daytime $\mathrm{C}$ assimilation, corrected for $2 \times$ the overnight loss of $\mathrm{C}$, is plotted against an independent method for estimating GPP over the daytime period $\left({ }^{18} \mathrm{O}\right.$ method of Bender et al. 1992) (Fig. 5). A Model II linear regression (E. T. Peltzer pers. comm.; see www.mbari. org/staff/etp3/regress.htm) of the data departs from the expected 1:1 relationship. The regression coefficient $(0.86 \pm 0.027)$, however, is not significantly different from 1 ( $p>0.05)$. Nevertheless, the differences, especially those at higher GPP, can be ascribed to grazing by microherbivores, experimental error, diel changes in the appearance of $\mathrm{DO}^{14} \mathrm{C}$ (all of which might reduce the dark loss), or non-fulfillment of one or more of the assumptions in Marra \& Barber (2004) (stated above).

If microherbivory were the cause of the departure from the 1:1 relationship, an offset would be expected rather than a change in slope, since fewer phytoplankton would be present to contribute to GPP. Otherwise, grazing at night would have to be greater than during the day, and grazers would have to have a much lower respiration rate than the phytoplankton. Experimental error could occur because samples might not have been removed from overnight incubations soon enough and have been exposed to early morning light, decreasing the dark loss. Such errors would be more apparent for higher values of GPP. DO ${ }^{14} \mathrm{C}$ release was not monitored, but a decrease in apparent $\mathrm{C}$ loss overnight would occur if release was proportional to photosynthesis during the day and the released DOC was then taken up by bacteria at night (Marra et al. 1988). On the other hand, following Maske \& Garcia-Marquez (1994), our methods of filtering the samples probably assayed $\mathrm{DO}^{14} \mathrm{C}$ as part of the particulate fraction. Despite these concerns, the near 1:1 relationship in Fig. 5 suggests that the assumptions cannot be too far off. Experimental error is the most likely and simplest explanation for the differences observed. The estimates of daily respiration rates in phytoplankton from the Marra \& Barber (2004) method are $\sim 35$ to $40 \%$, which agree with that found by Robinson \& Williams (2005) from indirect methods.

I have excluded one other data set from 2 experiments conducted at the Marine Ecosystem Research Laboratory (MERL) in 1983 (Bender et al. 1987) from Fig. 5 for 2 reasons. First, the MERL tanks enclosed an estuarine community with possible long-term containment effects and with a perturbed food web (Berg et al. 1999). One experiment atypically had no C loss overnight and 30 to $40 \%$ extracellular release, which is $\sim 100 \times$ the expected values (Strom et al. 1997). In the other experiment, which exhibited dark loss, the com- parison between ${ }^{18} \mathrm{O}$ GPP and corrected daytime $\mathrm{C}$ assimilation (in $\mathrm{O}_{2}$ units) was $110\left({ }^{18} \mathrm{O}\right)$ and $132\left({ }^{14} \mathrm{C}\right.$ corrected) $\mu \mathrm{M} \mathrm{d}^{-1}$, which is $\sim 7 \times$ higher than the range considered in Fig. 5. The 2 experiments at MERL differed widely for reasons that are unclear.

Like any comparison between $\mathrm{O}_{2}$ and $\mathrm{C}$ dynamics, the data in Fig. 5 are sensitive to the choice of photosynthetic quotient (PQ), which is similar to issues involved in converting nitrogen to $\mathrm{C}$ using Redfield ratios. Because nitrate was the nutrient source for both the spring bloom in the North Atlantic and for the monsoons in the Arabian Sea, we have used a PQ of 1.4 (Laws 1991, Bender et al. 1992). The current view is that the PQ issue is fairly well resolved (Davies \& Williams 1984).

As expected from the way it is calculated, phytoplankton respiration is related to photosynthesis. Traditionally, respiration has been thought to be relatively constant, and that idea formed the basis, for example, of the critical depth theory (Sverdrup 1953). Although it has become clear that respiration is more closely tied to photosynthesis or irradiance (Geider 1992, Langdon 1993), oceanographers have used a rate of respiration that is independent of depth, and therefore of irradiance or photosynthesis (Siegel et al. 2002), because phytoplankton respiration cannot be measured in natural populations. Respiration is now considered to consist of a (basal) rate for maintenance and a rate associated with growth (Laws \& Caperon 1976, Geider 1992). Therefore, the idea of respiration being a function of irradiance (with the intercept value being the maintenance respiration rate) is now generally accepted, if not always practiced.

Laws et al. (2000) presented an excellent analysis of $\mathrm{C}$ and $\mathrm{O}_{2}$ losses: they attempted to reconcile the differences between ${ }^{14} \mathrm{C}$ based productivity measurements and ${ }^{18} \mathrm{O}$ estimates of GPP. Laws et al. (2000) considered the Mehler reaction, grazing, and DOC release, as well as dark respiration during incubations, with dark respiration being the most important contributor to the difference. The combined effects of the Mehler reaction, photorespiration, and grazing could account for a $30 \%$ difference between ${ }^{14} \mathrm{C}$ uptake and ${ }^{18} \mathrm{O}_{2}$ evolution. However, there were no measurements of these in the data set analyzed. Extracellular release of DOC may be important, but this cannot be assumed a priori.

\section{CONCLUSIONS}

The foregoing has summarized evidence supporting the premise that ${ }^{14} \mathrm{C}$ assimilation measures net production (and probably NPP) relative to $\mathrm{O}_{2}$ fluxes. This occurs through refixation of respiratory $\mathrm{CO}_{2}$. Dring \& Jewson (1982) were correct in concluding that ${ }^{14} \mathrm{C}$ 
assimilation is proportional to GPP, but comparison with $\mathrm{O}_{2}$ fluxes allows further insight. Incubations with lake- or seawater will, of course, include heterotrophic activities, and there remains the question of the participation of these activities in ${ }^{14} \mathrm{C}$ assimilation incubations. Although I cannot draw a definitive conclusion for natural populations, prior evidence (Marra 2004), the linear time courses of assimilation, and the fact that we can approximate GPP by considering the overnight loss of $\mathrm{C}$ (Fig. 5), all support the idea that the ${ }^{14} \mathrm{C}$ method is a good estimator of NPP.

The ${ }^{14} \mathrm{C}$ method is best interpreted when incubations are conducted from dawn-to-dusk since any heterotrophic activity is minimized (with respect to autotrophic activity), metabolic equilibrium (with respect to ${ }^{12} \mathrm{C}$ and ${ }^{14} \mathrm{C}$ ) within the phytoplankton cells will have been attained, and production can be compared to daily irradiance. I have shown evidence where a dawn-todusk incubation agrees with other estimates of net (community) production (e.g. Fig. 4), as long as the water column is relatively stable. During storms, high internal wave activity, or other situations where the water column structure changes rapidly, the better recourse is to use highly time-resolved measurements, such as fluorescence-based measures or in situ biooptical sensor observations, with the aim of appropriately integrating these over the day.

The estimates of phytoplankton respiration are reasonable and promising, but the method outlined (based on the dark loss of ${ }^{14} \mathrm{C}$ ) requires much further research. Marra \& Barber (2004) analyzed previously existing data, and it would be beneficial to organize a research program with the objective of testing the hypothesis that a multiple of the dark loss provides an estimate of daily phytoplankton respiration. The data available include only locations with $\sim 12 \mathrm{~h}$ light:dark cycles. It is not known whether the method will work if we impose the same L:D cycle during polar summers, for example. If the method can be supported, then a series of questions regarding respiration in the ocean can be addressed: the balance between heterotrophic and autotrophic respiration, geographical differences, environmental control, and seasonal changes.

Acknowledgements. I thank my close collaborators on the PRPOOS program, R. W. Eppley, P. J. Le B. Williams, E. Laws, D. Redalje, M. Bender, and K. Grande for their many contributions; K. Heinemann, E. Renger, and D. Long for technical assistance; my colleagues in the JGOFS program, R. T. Barber, M. Bender, C. Brown, M. L. Dickson, M. Hiscock, Z. Johnson, and J. Kiddon for their help, advice, and fruitful collaborations; and C. Knudson, K. Heinemann, E. Barber, and J. Orchardo for technical assistance. I also thank 2 anonymous reviewers for their insights and advice, which greatly improved the manuscript.

\section{LITERATURE CITED}

Barber RT, Hilting AK (2002) History of the study of plankton productivity. In: Williams PJLeB, Thomas DN, Reynolds CS (eds) Phytoplankton productivity in marine and aquatic environments. Blackwell Science, Oxford, p 16-43

Barber RT, Sanderson MP, Lindley ST, Chai F and others (1996) Primary productivity and its regulation in the equatorial Pacific during and following the 1991-1992 El Nino. Deep-Sea Res II 43:939-969

Bender M, Grande K, Johnson K, Marra J and others (1987) A comparison of four methods for the determination of planktonic community metabolism. Limnol Oceanogr 32: 1085-1098

Bender M, Ducklow H, Kiddon J, Marra J, Martin JH (1992) The carbon balance during the 1989 spring bloom in the North Atlantic Ocean 47N/20W. Deep-Sea Res 39:1707-1725

Berg GM, Glibert PM, Chen CC (1999) Dimension effects of enclosures on ecological processes in pelagic systems. Limnol Oceanogr 44:1331-1340

Berman T, Kaplan B (1984) Respiration of Lake Kinneret microplankton measured by carbon loss in the dark. Arch Hydrobiol Beih Ergeb Limnol 19:157-162

Bidwell RGS (1977) Photosynthesis and light and dark respiration in freshwater algae. Can J Bot 55:809-818

Brown SL, Landry MR, Christensen S, Garrison D, Gowing MM, Bidigare RR, Campbell L (2002) Microbial community dynamics and taxon-specific phytoplankton in the Arabian Sea. Deep-Sea Res II 49:2345-2376

Buessler KO, Bacon MP, Cochran JK, Livingston HD (1992) Carbon and nitrogen export during the JGOFS North Atlantic Bloom Experiment estimated from 234Th:238U disequilibria. Deep-Sea Res I 39:1115-1137

Carr ME, Friedrichs MAM, Schmeltz M, Aita MN and others (2006) A comparison of global estimates of marine primary production from ocean color. Deep-Sea Res II 53:741-770

Chipman D, Marra J, Takahashi T (1993) Primary production at $47^{\circ} \mathrm{N} / 20^{\circ} \mathrm{W}$ : a comparison between the ${ }^{14} \mathrm{C}$ incubation method and mixed layer carbon budget observations. Deep-Sea Res II 40:151-169

Davies JM, Williams PJLeB (1984) Verification of ${ }^{14} \mathrm{C}$ and $\mathrm{O}_{2}$ derived primary production measurements using an enclosed ecosystem. J Plankton Res 3:457-474

del Giorgio PA, Duarte CM (2002) Respiration in the open ocean. Nature 420:379-384

> Dring MJ, Jewson JH (1982) What does the ${ }^{14} \mathrm{C}$ uptake by phytoplankton really measure? A theoretical modelling approach. Proc R Soc Lond B Biol Sci 214:351-368

Eppley RW (1972) Temperature and phytoplankton growth in the sea. Fish Bull 70:1063-1085

Eppley RW, Sharp JH (1975) Photosynthetic measurements in the central North Pacific: the dark loss of carbon in 24-h incubations. Limnol Oceanogr 20:981-987

> Falkowski PG, Barber RT, Smetacek V (1998) Biogeochemical controls and feedbacks on ocean primary production. Science 281:200-206

Fitzwater SE, Knauer GA, Martin JH (1982) Metal contamination and its effect on primary production measurements. Limnol Oceanogr 27:544-551

Geider RJ (1992) Respiration: taxation without representation? In: Falkowski PG, Woodhead A (eds) Primary productivity and biogeochemical cycles in the sea. Plenum, New York, p 333-360

> Grande KD, Marra J, Langdon C, Heinemann KR, Bender ML (1989a) Rates of respiration in the light measured in marine phytoplankton using an ${ }^{18} \mathrm{O}$ isotope-labeling technique. J Exp Mar Biol Ecol 129:95-120 
Grande KD, Williams PJLeB, Marra J, Purdie DA, Heinemann K, Eppley RW, Bender ML (1989b) Primary production in the North Pacific central gyre: a comparison of rates determined by the ${ }^{14} \mathrm{C}, \mathrm{O}_{2}$ concentration and ${ }^{18} \mathrm{O}$ methods. Deep-Sea Res 36:1621-1634

Hendricks MB, Bender ML, Barnett BA (2004) Net and gross $\mathrm{O}_{2}$ production in the southern ocean from measurements of biological $\mathrm{O}_{2}$ saturation and its triple isotope composition. Deep-Sea Res I 51:1541-1561

Johnson Z, Bidigare RR, Goericke R, Marra J, Trees C, Barber RT (2002) Photosynthetic physiology and physiochemical forcing in the Arabian Sea, 1995. Deep-Sea Res II 49:415-436

Knudson CA, Chamberlin WS, Marra J (1989) Primary production and irradiance data for US JGOFS (Leg 2) ATLANTIS II (Cruise 119-4). Lamont-Doherty Earth Observatory, Palisades, NY, p 11

Koblentz-Mishke OJ, Volkovinsky VV, Kabanova YG (1970). Plankton primary production in the world ocean. In: Wooster W (ed) Scientific exploration of the South Pacific Ocean. Nat Acad Sci, Washington, DC, p 183-193

> Lancelot C, Mathot S (1985) Biochemical fractionation of primary production by phytoplankton in Belgian coastal waters during short- and long-term incubations with ${ }^{14} \mathrm{C}$ bicarbonate. Mar Biol 86:219-226

Langdon C (1993) The significance of respiration in production measurements based on oxygen. ICES Mar Sci Symp 197:69-78

Laws EA (1984) Improved estimates of phytoplankton carbon based on ${ }^{14} \mathrm{C}$ incorporation into chlorophyll a. J Theor Biol 110:425-434

Laws EA (1991) Photosynthetic quotients, new production and net community production in the open ocean. DeepSea Res 38:143-167

Laws EA, Caperon J (1976) Carbon and nitrogen metabolism by Monochrysis lutheri: measurement of growth-rate dependent respiration rates. Mar Biol 36:85-97

Laws EA, DiTullio GR, Redalje DG (1987) High phytoplankton growth and production rates in the North Pacific subtropical gyre. Limnol Oceanogr 32:905-918

Laws EA, Landry MR, Barber RT, Bender M, Campbell L, Dickson ML, Marra J (2000) Carbon cycling in primary production bottle incubations: inferences from grazing experiments and photosynthetic studies using ${ }^{14} \mathrm{C}$ and ${ }^{18} \mathrm{O}$ in the Arabian Sea. Deep-Sea Res II 47:1339-1352

Li WKW, Goldman JC (1981) Problems in estimating growth rates of marine phytoplankton from short-term ${ }^{14} \mathrm{C}$ assays. Microb Ecol 7:113-121

Li WKW, Harrison WG (1982) Carbon flow into the end-products of photosynthesis in short and long incubations of a natural phytoplankton population. Mar Biol 72:175-182

Marra J (1995) Bioluminescence and optical variability in the ocean: an overview of the Marine Light-Mixed Layers Program. J Geophys Res 100:6521-6525

Marra J (2002) Approaches to the measurement of plankton production. In: Williams PJLeB, Thomas DN, Reynolds CS (eds) Phytoplankton productivity in marine and aquatic environments. Blackwell Science, Oxford, p 78-108

Marra J (2004). Reply to 'A comment on Marra's ${ }^{14} \mathrm{C}$ uptake by phytoplankton, now and in the future' by A. G. Moigis'. Limnol Oceanogr Bull 13:7-9

Marra J, Barber RT (2004) Phytoplankton and heterotrophic respiration in the surface layer of the ocean. Geophys Res Lett 31:L09314

Marra J, Haas LW, Heinemann KR (1988) Time course of C assimilation and microbial food web. J Exp Mar Biol Ecol 115: $263-280$

Marra J, Langdon C, Knudson C (1995) Primary production, water column changes, and the demise of a Phaeocystis bloom at the Marine Light-Mixed Layers site $\left(59^{\circ} \mathrm{N}, 21^{\circ} \mathrm{W}\right)$ in the northeast Atlantic Ocean. J Geophys Res 100: 6633-6643

> Maske H, Garcia-Marquez E (1994) Adsorption of dissolved organic matter to the inorganic filter substrate and its implications for ${ }^{14} \mathrm{C}$ uptake measurements. Appl Environ Microbiol 60:3887-3889

Peltier G, Thibault P (1985) $\mathrm{O}_{2}$ uptake in the light in Chlamydomonas: evidence for persistent mitochondrial respiration. Plant Physiol 79:225-230

Peterson BJ (1980) Aquatic primary productivity and the ${ }^{14} \mathrm{C}$ $\mathrm{CO}_{2}$ method: a history of the productivity problem. Annu Rev Ecol Sys 11:359-385

Pringault O, Tassas V, Rochelle-Newall E (2007) Consequences of respiration in the light on the determination of production in pelagic systems. Biogeosciences 4:105-114

Pringault O, Tesson S, Rochelle-Newall E (2009) Respiration in the light and bacterio-phytoplankton coupling in a coastal environment. Microb Ecol 57:321-334

Raven JA (1972) Endogenous inorganic carbon sources in plant photosynthesis. I. Occurrence of the dark respiratory pathways in illuminated green cells. New Phytol 71:227-247

Robinson C, Williams PJLeB (1999) Plankton net community production and dark respiration in the Arabian Sea during September 1994. Deep-Sea Res I 46:745-765

Robinson C, Williams PJLeB (2005) Respiration and its measurement in surface marine waters. In: del Giorgio $\mathrm{P}$, Williams PJLeB (eds) Respiration in aquatic ecosystems. Oxford University Press, Oxford, p 147-179

Ryther JH (1956a) The measurement of primary production. Limnol Oceanogr 1:72-84

Ryther JH (1956b) Interrelation between photosynthesis and respiration in the marine flagellate Dunaliella euchlora. Nature 178:861-863

> Siegel DA, Doney SC, Yoder JA (2002) The North Atlantic spring phytoplankton bloom and Sverdrup's critical depth hypothesis. Science 296:730-733

- Smith REH, Platt T (1984) Carbon exchange and ${ }^{14} \mathrm{C}$ tracer methods in a nitrogen-limited diatom Thalassiosira pseudonana. Mar Ecol Prog Ser 16:75-87

Steemann Nielsen E (1952) The use of radio-active carbon (C14) for measuring organic production in the sea. J Cons Int Explor Mer 18:117-140

> Steemann Nielsen E (1955) The interaction of photosynthesis and respiration and its importance for the determination of ${ }^{14} \mathrm{C}$-discrimination in photosynthesis. Physiol Plant 8: 945-953

Strom SL, Benner R, Ziegler S, Dagg MJ (1997) Planktonic grazers are a potentially important source of marine dissolved organic matter. Limnol Oceanogr 42:1364-1374

Sverdrup HU (1953) On conditions for the vernal blooming of phytoplankton. J Cons Int Explor Mer 18:287-295

Weger HG, Birch DG, Elrifi IR, Turpin DH (1988) Ammonium assimilation requires mitochondrial respiration in the light. A study with the green alga Selenastrum minutum. Plant Physiol 86:688-692

Weger HG, Herzig R, Falkowski PG, Turpin DH (1989) Respiratory losses in the light in a marine diatom: measurements by short-term respirometry. Limnol Oceanogr 34: $1153-1161$

Williams PJleB, Heinemann KR, Marra J, Purdie DA (1983) Comparison of ${ }^{14} \mathrm{C}$ and $\mathrm{O}_{2}$ measurements of phytoplankton production in oligotrophic waters. Nature 305:49-50

Williams PJleB, Thomas DN, Reynolds CS (2002) Phytoplankton productivity: carbon assimilation in marine and freshwater ecosystems. Blackwell Science, Oxford 